\title{
A tengerek és óceánok müanyag szennyezésének komplex hatása - 1. rész: A probléma bemutatása
}

\author{
Gubek István \\ Eötvös Loránd Tudományegyetem, Humánökológia MA, \\ 1117 Budapest, Pázmány Péter sétány 1/A \\ e-mail: istvan.elte@gmail.com
}

\begin{abstract}
Összefoglaló: A tengerek és óceánok műanyag szennyezése az utóbbi évek egyik egyre többet kutatott témája. Hasonlóan globális szintü környezeti probléma, mint az éghajlatváltozás vagy a biodiverzitás csökkenése, ugyanakkor a közvélemény sokkal kevesebbet tud róla, mivel ez egy új kutatási terület, illetve nincs magyar nyelvü szakirodalom a témában. Ez az első átfogó összeállítás, mely a külföldi szakirodalom részletes áttanulmányozásával készült. Az első részben részletes leírást adok a tengeri környezetbe került müanyagok fizika, kémiai, biológia, ökológiai, gazdasági és társadalmi hatásairól, a második, befejező részben pedig bemutatom a már létező megoldási lehetőségeket.
\end{abstract}

Kulcsszavak: tengerek, óceánok, müanyagok, környezetszennyezés, hulladékszigetek, biodiverzitás, ökoszisztémák, tápláléklánc

\section{Bevezetés}

Ahogy az emberiség egyre sokasodik és egyre inkább igénybe veszi a Föld erőforrásait valamint hulladék-asszimiláló képességét, elkerülhetetlen, hogy újabb és újabb környezeti problémákkal kerüljön szembe. A 20. században 40-szeresére nőtt a világ ipari termelése, a világ népessége pedig több mint 3,5-szeresére. Mindez azt eredményezte, hogy mára már 1,5 Föld kellene az emberiség fenntartható ellátásához (McNeill 2011). Jelenleg a két legnagyobb globális környezeti probléma a globális éghajlatváltozás és a biodiverzitás csökkenése (Rockström et al. 2009). Az utóbbi 40 év kutatásai alapján azonban nyilvánvalóvá vált, hogy egy újabb, globális méretü környezeti probléma alakult ki a tengerek és óceánok műanyag elszennyezésének következtében (STAP 2011). Tanulmányomban bemutatom, hogy milyen hatása van annak az évi több millió tonna mủanyag hulladéknak, mely a tengerekbe, óceánokba kerül. Az óceáni áramlatok összesen öt hatalmas, egyenként több 100 ezer $\mathrm{km}^{2}$ kiterjedésủ hulladékfoltot hoztak létre a Csendes-, az Atlanti- és az Indiai-óceánon. A legnagyobb gondot azonban az je- 
lenti, hogy a mủanyag még hosszú évek, évtizedek, évszázadok alatt sem bomlik le, csak felaprózódik és felhalmozódik az óceánok közepén, a tengerpartokon, a szigetek partjain és a táplálékláncban. Ráadásul ezek a mikrométeres müanyag szemcsék felületükön megkötik a kis koncentrációban jelen lévő mérgező szerves ipari szennyezőanyagokat, melyek így feldúsulva jutnak az élőlények szervezetébe, legvégül pedig az emberbe. A müanyagszennyezés azonban nemcsak a tengeri ökoszisztémák egészségét fenyegeti, hanem a fennmaradásukat is, hiszen elősegíti az invazívvá váló fajok terjedését, ami a kevéssé ellenálló, helyi fajok eltűnéséhez vezethet. A probléma komplexitását mutatja, hogy a negatív ökológiai hatásokon túl negatív gazdasági és társadalmi hatásokkal is számolnunk kell. A tengerpartok tisztán tartása, az akvakultúrák fenntartása, a turizmus visszaesése, a tengeri élelmet fogyasztó emberek egészségi állapota mind-mind közvetlen kapcsolatban áll ezzel a még kevésbé ismert, de annál jelentősebb környezetkárosítással. Szükség van tehát az azonnali, átfogó cselekvési programokra. Ezeket a cikk folytatásában ismertetem.

\section{Mủanyagok a Földön}

A müanyagok a modern kor iparának egyik legnagyobb mennyiségben előállított termékei. Tömegtermelésük 1950-től vált jelentőssé, akkor évi 1,5 millió tonnát állítottak elö. Azóta folyamatosan és drasztikusan növekedett a megtermelt menynyiség (átlagosan évi 9\%-kal), ennek eredményeképp 2012-ben már 288 millió tonna múanyagot gyártottak (1. ábra). A tengerekbe, tengerpartokra a müanyag hulladék körülbelül 10\%-a kerül (Krause et al. 2006) a szél, folyók, csatornák és szennyvíz közvetítésével (Wright et al. 2013), ami évi több millió tonnát jelent. A pontos értéket nem is lehet megbízhatóan megbecsülni, mindenesetre jelentős mennyiségről van szó. A 90-es évek elején csak a hajókról évi közel 6,5 millió tonna müanyag hulladék került az óceánokba (Derraik 2002). A termelés növekedésével párhuzamosan tehát a tengeri környezetbe kerülő müanyagok mennyisége is nő (STAP 2011). Figyelembe véve a termelődő szilárd hulladék mennyiségét, összetételét, a népsürüséget, a gazdasági fejlettséget és a hulladékkezelést, azt állapították meg amerikai kutatók, hogy 2010-ben átlag 8,75 millió tonna került be a tengeri környezetbe, ami az abban az évben elóállított 275 millió tonna müanyag 3\%-a (Jambeck et al. 2015). A folyamatos növekedésben két kisebb visszaesést látunk: a 1970-es évek olajválságát (a kőolaj 8\%-ából műanyag készül) és a 2008as gazdasági világválságot.

Elóállításuk jellemzően fosszilis nyersanyagokból történik: kőolajból, szénből és földgázból, így elégetésükkel hozzájárulnak a klímaváltozáshoz, ráadásul 


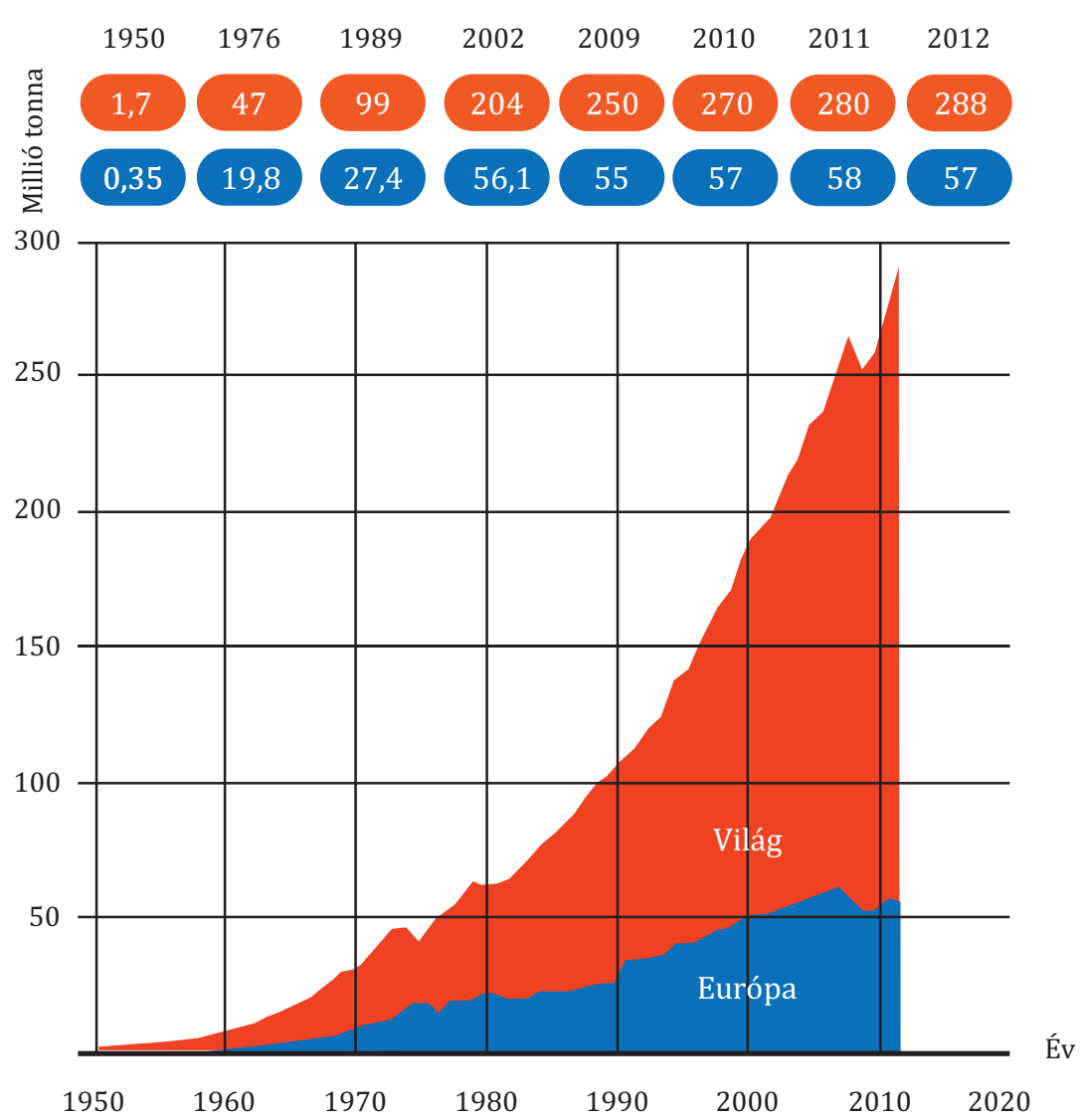

1. ábra. A müanyaggyártás növekedése a világban és Európában (ábra forrás: PlasticsEurope 2013).

közben erőteljesen szennyezik a környezetet, mivel hosszú tartózkodási idejü és mérgező anyagok, furánok és dioxinok keletkeznek. Legelterjedtebbek a szintetikus mủanyagok, melyek a világtermelés $90 \%$-át adják, szemben a természetes alapúakkal, melyek részesedése $10 \%$. Ez azért probléma, mert a szintetikus polimerekhez gyakran adnak veszélyes adalékanyagokat, mint például lágyítókat vagy BPA-t (biszfenol A). Gyors elhasználódásuk nagyban megnöveli a keletkező hulladék mennyiségét: PET palackok, csomagolóanyagok, egyszer használatos evőeszközök, poharak, bevásárlószatyrok, orvosi eszközök kerülnek a szemétbe. Lebomlásuk nem, vagy csak évtizedek alatt megy végbe szárazföldön (Shah et al. 2008). Tengeri környezetben pedig évszázadokig, sőt évezredekig is eltarthat ez a folyamat (Kaposi et al. 2013). Miközben egyre jobban felaprózódnak, megkötik a kémiai szennyeződéseket és beépülnek a tengeri ökológiai rendszerekbe. 
Mindez döntően hozzájárul az óceánok fizikai szennyezéséhez, mivel a lebegő tengeri törmelék 90\%-át, az összes tengeri szemét 60-80\%-át műanyag teszi ki (Derraik 2002, Setälä et al. 2014). A fennmaradó részt üvegpalackok, ruhadarabok, fémdarabok, építési faanyag, kötelek, cigaretta-csikkek, növényi és állati eredetü szerves anyagok alkotják.

A jelenlegi jövőkép nem túl bíztató. A termelés növekedésével együtt a müanyagok iránti kereslet is egyre nő. A fejlett országok közül Közép-Európában - ahová hazánk is tartozik - a legnagyobb a növekedés: áltagosan évi 7,3\%. Ez azt eredményezte, hogy ebben a régióban az elmúlt 35 évben ötszörösére nőtt az egy főre jutó évi múanyag használat, ami jelenleg kb. $45 \mathrm{~kg} /$ fö/év. A fejlődő országokban is gyorsan nő a múanyagok fogyasztása, olyannyira, hogy egyre inkább áttevődik ide a gyártás folyamata.

Exponenciálisnak tekinthető a növekedés Ázsiában: a 21. század első évtizedében, 2000 és 2010 között több múanyagot gyártottak, mint korábban az egész 20. században (STAP 2011). Ez az óriási növekedés minden bizonnyal folytatódni fog a következő években is: az előrejelzések szerint 2050-re megháromszorozódhat a termelés, 700 millió tonna fölé nőhet (Wurpel et al. 2011). Így egyre sürgetőbbé válnak az egyéni, vállalati, kormányzati és nemzetközi szintü intézkedések a probléma kezelésére. Amennyiben nem történik semmi, 2025-re egy nagyságrenddel lesz nagyobb az évenkénti szennyezés mértéke is: a több tízmillió tonnát is elérheti. A legnagyobb problémát a keleti-, délkeleti-ázsiai régió jelenti Kínával és Indonéziával az élen (Jambeck et al. 2015).

2016 januárjában jelent meg a davosi Világgazdasági Fórum tanulmánya, mely még nagyobb aggodalomra ad okot. Töretlenül tovább növekszik a mủanyaggyártás Európában és a világon - ezzel együtt pedig a környezetbe, tengerekbe kerülő hulladék mennyisége is -, melynek fö összetevői a különféle csomagolóanyagok. Ha minden így folytatódik tovább, 2050-re a tengerekben, óceánokban felhalmozódó müanyagok tömege meg fogja haladni az ott élő halak tömegét (WEF 2016).

\section{A tengerek új típusú szennyezői}

A 70-es években figyeltek fel a kutatók elöször a múanyagok okozta újabb környezeti problémára. Már 1971-ben publikálták, hogy a tengerbe került és feldarabolódott müanyag potenciális veszélyt jelent a tengeri élőlények számára. Egy évvel később - 1972-ben - halakban meg is találták az első müanyag szemcséket. Kezdetben csak fizikai szempontból vizsgálták a mủanyagok hatásait, dokumentálták az óceánokban mérhető koncentráció növekedését, a halakban és madarakban történő egyre nagyobb mértékű felhalmozódását. Azokra a sokkal jelentősebb, bio- 
kémiai hatásokra, hogy a műanyaggal együtt mérgező szerves szennyeződések is bekerülnek az élőlények szervezetébe azonban csak a 2000-es években figyeltek fel. A 2010-es évektől kezdve ugrásszerủen nőtt a témával foglalkozó kutatások száma, mivel az egyre fokozódó tengeri mủanyag szennyezés egyre fenyegetőbb és egyre komplexebb problémává vált. Már nemcsak az egyes tengeri élőlényekre fejtette ki negatív hatását, hanem az egész tengeri ökológiai rendszerre. Megjelent az óceáni szigetek partvonalán is (Hawaii-szigetek, Bermuda-szigetek, Húsvétsziget, Kanári-szigetek) így az ottani élővilág is veszélybe került. A tengerpartok szennyezettsége is fokozódott (Japán, Chile). Hatása kimutathatóvá vált gazdasági (halászat, parttisztítás, turizmus) és társadalmi (egészség és biztonság) szinten is (Do Sul \& Costa 2014).

Számtalan módon kerülhetnek müanyagok a tengeri környezetbe. Mindenekelőtt meg kell különböztetni a műanyagok két típusát: a fogyasztók által használt termékeket és az ipari gyártás alapanyagául szolgáló apró granulátumokat. A fogyasztói múanyagokat nyolc fó csoportba lehet osztani (Andrady 2011):

- PP (Polipropilén): kötelek, hálók, kupakok

- $\quad$ LDPE (Kis sürüségü polietilén): szatyrok, fóliák, jármüvekben

- PVC (Poli(vinilklorid)): csövek, szigetelések

- $\quad$ HDPE (Nagy sürüségü polietilén): csomagolás, palackok

- PET (Polietilén-tereftalát): palackok, müszálak

- PS (Polisztirol): ételhordók, evőeszközök

- PA (Poliamid, nylon): horgász-zsinór, müszálak

- CA (Cellulóz-acetát): cigaretta-filterek

Ezen termékek két forrásból kerülhetnek az óceánokba. Szárazföldi környezetből (ami magába foglalja a nem megfelelően felügyelt hulladéklerakókat is): a folyók, a kezeletlen szennyvíz és a szél transzportja révén; a tengerpartokról nagyobb viharok, hurrikánok, cunamik idején, rekreációs célú használat közben. Tengeri környezetből: hajózás, szállítás, halászat, tengeri gazdálkodás (akvakultúrás tenyésztés) során. A turizmus mindkét esetben szennyezhet.

A müanyagok ipari gyártása során mügyanta szemcsék kerülnek ki a környezetbe. Ezek a kicsi, $0,1-0,5 \mathrm{~cm}$ átméröjü, $25 \mathrm{~cm}^{2} / \mathrm{g}$ fajlagos felületü, hengeres vagy lapos granulátumok a mủanyaggyártás ipari nyersanyagai. E granulátumokat megolvasztva és formába öntve készítik el a kívánt mủanyag terméket. A szállítási és a gyártási folyamat során akaratlanul is kikerülnek közvetlenül a tengeri vagy szárazföldi környezetbe. Ez utóbbi esetben a felszíni lefolyással szintén a tengerekbe jutnak. Azokban a térségekben, ahol elmaradott a környezetvédelem, szándékosan is így szabadulnak meg a megmaradt vagy feleslegessé vált szemcséktől. Mivel nehezen bomlanak le, egyre nagyobb mértékben halmozódnak fel 
az óceánokban és a tengerpartokon. Először 1972-ben észlelték az Atlanti-óceán észak-nyugati részén, azóta világszerte minden homokos tengerparton megfigyelhetők. A korábban kibocsátott, idősebb szemcsék nagyobb mérgező hatást mutatnak (több szerves szennyezést kötöttek meg), így a szennyezettség indikátoraivá váltak. Világszerte rendszeresen gyüjtenek mintákat, hogy nyomon kövessék a partok és parti vizek állapotának változását (Barnes et al. 2009).

A folyók transzport szerepének jelentőségét jól mutatja egy 2014 elején megjelent német publikáció a Duna szennyezettségével kapcsolatban (Lechner et al. 2014). Két éven át vizsgálták Európa második legnagyobb folyójának Bécs és Pozsony közti szakaszát és megállapították, hogy $1000 \mathrm{~m}^{3}$ vízben átlagosan 3,2 g (275 db) halivadék és 4,8 g (317 db, $500 \mu \mathrm{m}$ és $5 \mathrm{~cm}$ közti) müanyag darab található. Ez azt jelenti, hogy 15\%-al több a Dunában a mủanyag hulladék, mint a fejlődésben lévő halak száma. Ráadásul még így is alulbecsülték a szennyezettséget, hiszen a mintavételező háló csak a $0,5 \mathrm{~mm}$-nél nagyobb darabokat fogta fel. A kutatók becslése szerint napi 4,2 tonna, évente pedig 1533 tonna mủanyag törmelék kerül így a Fekete-tengerbe, melynek 80\%-a ipari eredetü, a már említett mügyanta szemcsékkel kapcsolatos. Ez több mint az Észak-Atlanti-óceán hulladéksziget becsült tömege, ami 1100 tonna. A kutatás jelentősége, hogy ez volt első olyan vizsgálat, ami egy európai folyóban a mủanyagok transzportját vizsgálta. Rávilágít arra is, mekkora veszélyt jelent ez a dunai halállományra nézve: ha a kis halak lenyelik a műanyag hulladékot közvetlenül bélelzáródásban vagy közvetetten, a mủanyagon megkötött toxinok miatt, mérgezésben is meghalhatnak. A nagyobb halakban pedig felhalmozódnak a táplálékkal együtt felvett szemcsék és toxinok, így az emberi szervezetbe is bejuthatnak. Potenciális veszélyforrássá vált tehát a dunai halfogyasztás. Kaliforniában 2004-ben és 2005-ben két folyóban vizsgálták az $5 \mathrm{~mm}$ átmérő alatti müanyag darabokat. A szállított mennyiség itt is jelentős: 3 nap alatt 2,3 milliárd plasztikszemcsét juttattak el a Csendes-óceánba ( 60 t) (Moore 2008).

A múanyagszennyezést két mérettartományra lehet bontani, bár ez a felosztás nem egységes (Cole et al. 2011). A makroplasztikumok (fogyasztói mủanyagok) 5 mm-nél nagyobbak, a mikroplasztikumok 5 mm-nél kisebbek. Utóbbiak lehetnek elsődlegesek, azaz eredendően ilyen méretüek: ipari mügyanta szemcsék, kozmetikumok mikroszemcséi, szemcseszórásos tisztítás koptatóanyagai, ruhák müszálai. Másodlagosak, ha a nagyobb darabok mérete a környezet degradáló hatása miatt csökkent le.

A tengeri szennyezés domináns forrása a makroplasztikum volt egészen az elmúlt évekig, amikor is jelentősen elkezdett növekedni a mikroplasztikumok aránya. Ennek oka a háztartásokban keletkező szennyvíz a müszálas textilek és ruhák mosása, valamint a mikroszemcsés tisztítószerek használata során. 
Egyre több szintetikus textilt és ruhát használ az emberiség. Ezek PS, akril és PA müszálakból épülnek fel. Egy kísérlet során ilyen anyagú takarókat, mügyapjakat és pólókat mostak ki több különféle mosógépben és azt az eredményt kapták, hogy egy átlagos mosás alkalmával egyetlen ruha-, illetve textildarab 1900-nál is több mikroszálat enged ki magából, s a keletkező szennyvíz literenként minden esetben 100-nál több mikroplasztikumot tartalmazott (Browne et al. 2011).

A másik nagy lakossági eredetü probléma a mikroszeszemcsés kéztisztítóknak, fogkrémeknek, arctisztítóknak, kozmetikai szereknek az elterjedése. Ezeket napi rendszerességgel használják az emberek. A bennük lévő PE, PP és PS granulátomokat mikrogyöngyöknek és mikro-hámlasztóknak hirdetik, melyek segítenek hatékonyan megtisztítani börünket. Régebben még természetes anyagokat tartalmaztak az arctisztítók (például habkő és dióhéj) mára már azonban felváltotta őket az olcsóbb, de hasonlóan hatékony mủanyag. Az ipari mủanyag szemcséktől könnyü megkülönböztetni őket: sokkal kisebbek (10-100 mikrométer nagyságúak) és szabálytalan formájúak (Fendall \& Sewell 2009).

A kutatásban az szerepel, hogy a szennyvíztisztítók nem tudják eltávolítani az 1,5 mm-nél kisebb müanyag szemcséket, ezért megkérdeztem a Fővárosi Csatornázási Mủvek Zrt.-t, hogy a lakossági eredetủ múanyag makro- és mikroszennyezés milyen módszerrel és hatásfokkal távolítható el a szennyvízből. Azt a választ kaptam, hogy a 10 mm-nél nagyobb szennyeződések eltávolítása gépi rácsokkal történik. Az ennél kisebb mủanyag-szennyeződések eltávolítására flotációs technológiát alkalmaznak, mely során a kombinált homokfogó mütárgyba, levegőztető turbinával nagyméretű buborékokat vezetnek. A felszínére került szennyeződést gépi kotrókkal távolítják el. A rácsszürés és a flotációs technológia után megmaradó kisebb méretü müanyag mikroszennyezők feltehetően beépülnek az eleveniszapba, így a fölösiszappal vagy az utóülepítőkön alkalmazott uszadék eltávolító berendezéssel eltávolításra kerülnek a szennyvízből, bár erre vonatkozó méréseket nem végeznek. Ezzel szemben egy amerikai tanulmány is kijelenti, hogy a mikroplasztikumokat minden bizonnyal nem távolítja el a hagyományos szennyvízkezelési eljárás, nagyrészt változatlan formában kerülnek ki a tisztítási folyamatból (Engler 2012).

A tengeri eredetủ források közül a halászat, a tengeri szállítás és az akvakultúrák a legjelentősebbek. Évente 640 ezer tonna halászati eszközt (hálót, kötelet) hagynak vagy dobnak el a világ óceánjaiban. Ez körülbelül 10\%-a az összes óceáni szemétnek. Az 1950-es években még természetes szálakból, kenderből és gyapotból szötték ezeket Délkelet-Ázsiában. Rugalmasságukat azonban használatuk során elvesztették, ezért eldobták őket. Ez azonban nem jelentett problémát, mivel gyorsan lebomlottak. A müanyagipar felfutásával később ezeket nylon (PA), poliolefin (PE, PP) és más szintetikus szálakkal helyettesítették. Tartósabbá és 
erősebbé váltak, viszont környezetbe kerülésük már gondot okozott: nem bomlottak le, a vízben vagy a felszínen lebegve szétterjedtek vagy az aljzatra süllyedve felhalmozódtak (Gregory 2009). A kereskedelmi hajók minden nap 639000 müanyag konténert szállítanak a világ óceánjain, ezek egy része elveszik az utazás, kirakodás, berakodás során és tartalmukkal együtt a tengeri szemét részévé válnak (Laist 1987). A tengeri tenyészetek szintén rendszeres szennyezőnek számítanak: a rákfarmokról műanyag szerkezeti elemek, a lazacfarmokról mủanyag élelmiszerzsákok kerülnek a tengerbe. Chilében a legrosszabb a helyzet, a kormány ezért szigorított a szabályozáson 2002-ben és 2008-ban is, de a hatóságok nem ellenőrzik kellőképpen a törvények betartatását. A helyi akvakultúrák továbbra is meghatározó forrásai a dél-csendes-óceáni szemétnek (Thiel et al. 2011).

\section{Fizikai hatás}

A különféle forrásokból tengerekbe került makro- és mikroméretủ plasztikumok idegen anyagnak számítanak és tartósan megmaradnak. Vízhez hasonló sürüségük miatt lebegnek, az áramlatok egyrészt csapdázzák őket, másrészt az óceán minden részére eljuttatják, a tengerpartokra és a távoli szigetekre is. Közben fizikai kölcsönhatásba lépnek az óceáni környezettel, egyre kisebb darabokra esnek szét, felhalmozódásuk megkezdődik a tengeraljzaton is. Ezeket fejtem ki a következőkben.

\section{Degradáció és diszperzió}

A mủanyagok sủrüsége hasonló, mint a tengervízé, ezért alapvetően a víztest felső régiójában helyezkednek el. Az 1,02-1,03 g/ $\mathrm{cm}^{3}$ - hőmérséklettől és sótartalomtól függö - értéknél kisebb sürüségúek a víz tetején, közvetlenül a vízfelszínen úsznak (PP, HDPE, LDPE), a nagyobb sürüségúek a vízfelszín alatt lebegnek (PS, PA, CA, PVC, PET) és nagyobb eséllyel süllyednek el. A felszínükön megtelepedő mikrobák tovább növelik sürüségüket. A felhasználói műanyagok gyakran több típusú polimerből tevődnek össze, lebegésük mélysége alapvetően összetételüktől és a bezárt levegőtartalomtól függ. További befolyásoló tényező az eső, a viharok és a turbulens vízmozgás, melyek dinamikus vertikális mozgást, keveredést idéznek elő. A gyártási arányokat és sürüségviszonyokat ismerve nem meglepő az a megállapítás, hogy az óceánokban a felszín közelében lebegő mikroplasztikumok 80-90\%-a PP, és 5-15\%-a PE (Engler 2012).

Az egyik előnyös tulajdonságuk - a nagy ellenállóságuk - most az egyik legnagyobb problémává válik: nem bomlanak le, csupán felaprózódnak egyre kisebb darabokra az UV-sugárzás, a hullámzás, az áramlások és a szél degradáló hatása 
miatt. Az évek, évtizedek alatt a milliméteres és mikrométeres szemcseméretet is elérhetik. Mindeközben fajlagos felületük nő, ami majd kémiai tulajdonságaiknál kap jelentős szerepet (Andrady 2011).

Az óceáni környezetben évezredekig is jelen lehetnek, amennyiben lejutnak a tengerfenékre, ahol alacsony hőmérsékleten, oxigén és fényhiányos környezetben leülepednek (Barnes et al. 2009).

A széllel és áramlatokkal meglepően gyorsan és messzire el tudnak jutni. Az egyik hajó elveszett mủanyag rakományát 10 évvel később 10000 km-rel odébb találták meg. Amerika északi tengerpartján végzett nyomkövetős vizsgálatban átlagosan 60 nap alatt érték el a müanyag darabok az 1000 km-re lévő észak-atlantióceáni szubtrópusi vízkörzési zónát (Cole et al. 2011).

\section{Az öt nagy hulladéksziget}

Az óceáni áramlatok nemcsak szétoszlatják a hulladékot, hanem csapdázzák is. A meleg és hideg áramlatok körkörös mozgása öt nagy hulladékszigetet hoz létre a Föld óceánjain. Az ide bekerülő mủanyagok éveken, évtizedeken át cirkulálnak a felszínen lebegve, miközben egyre jobban felaprózódnak. Az örvények közepén kisebb az áramlási sebesség, konvergáló zónaként viselkednek, begyüjtik és felhalmozzák környezetükből a műanyagokat. Három régiót tanulmányoztak eddig a kutatók részletesen: az észak-atlanti-óceáni (Law et al. 2010, Morét-Ferguson et al. 2010), az észak-csendes-óceáni (Moore et al. 2001) és a dél-csendes-óceániörvényt (Martinez et al. 2009, Eriksen et al. 2013). A dél-atlanti-óceáni- és indiai-óceáni-örvényt még nem vizsgálták meg alaposabban. Az északi féltekén az óramutató járásával megegyező irányban, a délin azzal ellentétesen forognak ezek az örvények. A jelenségnek több neve is van: szemétfolt (garbage patch), plasztik leves (plastik soup), müanyag szigetek (plastic islands), óceáni hulladéklerakó (ocean landfill) vagy szemétörvény (trash vortex). A nemzetközi szakirodalom leggyakrabban a „garbage patch” kifejezést használja. A modellezés müholdas nyomkövetés és terepi mérések, megfigyelések alapján történik. Rendszeresen indulnak kutatóexpedíciók is, hogy gyakorlatban is nyomon kövessék az óceánok szennyezettségének alakulását. Ezeket olyan független, nonprofit, civil szakmai szervezetek (NGO-k1 ${ }^{1}$ szervezik, mint a 5Gyres Intézet (http://www.5gyres.org) és az Algalita Tengerkutató Alapítvány (http://www.algalita.org). Önkéntesként bárki csatlakozhat az expedíciókhoz. Olyan feladatokban lehet segédkezni mint a mintavételezés, vizuális megfigyelés, adatelemzés vagy a partok állapotának felmérése.

$1 \mathrm{NGO}=$ Non-Governmental Organization (nem kormányzati szervezet). 
Ezen szervezetek felbecsülhetetlen értékủ munkát végeznek, mivel az így kapott információkkal fel lehet hívni a kormányok és a közvélemény figyelmét a helyzet súlyosságára és a szükséges intézkedések meghozására.

További veszélyt jelent, hogy az óceáni szemétszigetek láthatatlanok, így nem vizualizálódik a probléma. Egy nagy óceáni hulladéksziget közepén körbenézve nem tapasztalható semmi szokatlan a környező vízfelszínen, víztestben. Nem figyelhetők meg a szó szoros értelmében vett hulladékhegyek, sem hulladékszigetek. Csak a mintavétel után lesz egyértelmü, hogy ez már a szemétfolt. A konvergens zóna felé közeledve exponenciálisan nő a vízben lévő milliméteres és mikrométeres szemcsék száma. Az Észak-Atlanti-óceán szubtrópusi régiójában $20000-30000 \mathrm{db} / \mathrm{km}^{2}$ átlagos és $580000 \mathrm{db} / \mathrm{km}^{2}$ maximális koncentrációt mértek, ez háromszor több, mint a 70-es években (Law et al. 2010). Az Észak-Csendes-óceán örvényében $970000 \mathrm{db} / \mathrm{km}^{2}$ maximális sürüséget mértek 2001-ben (Japán partjainál) - ez háromszorosa volt a korábbi 1990-es maximumnak. Még egy meglepő eredmény született: a mintákban lévő mủanyag tömege hatszorosan meghaladta a planktonikus élőlényekét.

Azt, hogy pontosan mekkora egy óceáni szemétsziget, nem tudják a kutatók. Nincs definíció arra vonatkozólag, hogy milyen mủanyagsủrüségtől tekinthetjük az adott területet a sziget részének. Ideális esetben nulla antropogén eredetü részecskét tartalmaz a víztest egy $\mathrm{km}^{2}$-en. Gyakorlatilag ilyet már nem találni sehol. A hulladékörvények nagyságát viszont meg lehet becsülni: a konvergáló zónák mind az öt esetben $100000 \mathrm{~km}^{2}$ nagyságrendủek. Ez a hatalmas kiterjedés meglehetősen kis tömegsürüséggel jár: az észak-csendes-óceáni hulladékfoltban mindössze néhány $\mathrm{kg} / \mathrm{km}^{2}$. Lehetetlen vállalkozás lenne megpróbálni összegyüjteni őket.

A dél-csendes-óceáni konvergáló zónát 2013-ben vizsgálták meg másodszor a 5 Gyres Institue expedíciója során. Korábban nagyon kevés adat állt rendelkezésünkre a déli félteke óceánjainak szennyezettségéről, holott az Egyenlítőtől délre a terület $81 \%$-a tengervíz. A hulladéksziget modellt ismét alátámasztották: a centrum felé haladva ugrásszerüen nőtt, majd azt elhagyva hirtelen lecsökkent a mikroplasztikumok mennyisége. Az átlagos eloszlás $26000 \mathrm{db} / \mathrm{km}^{2}$, a maximális sürüség $396000 \mathrm{db} / \mathrm{km}^{2}$ müanyag darab volt. A minták 96\%-a tartalmazott müanyagot. Az adatok alapján a legnagyobb hulladéksziget az Észak-Csendesóceánon van, második az Észak-Atlanti-óceánon, legkevésbé szennyezett a DélCsendes-óceán, viszont ennek a legerőteljesebb a felhalmozódási képessége. A térség jó helyezése annak köszönhető, hogy a nyugati világ szemszögéből nézve gazdaságilag kevésbé fejlett országok veszik körül az óceán ezen részét (Peru, Chile, Ecuador, kis szigetállamok), így kisebb mértékü a szárazföldről érkező szennyezés. 
A kutatások elgondolkodtató eredménye, hogy az Atlanti-óceán északi részén a vizsgált 22 év alatt nem nőtt a plasztikumok mennyisége, annak ellenére, hogy az USA-ban erőteljesen nőtt a keletkező hulladék mennyisége. Ennek magyarázata az lehet, hogy alulbecsülték a szennyezettséget. A mintavétel minden esetben mantahálóval ${ }^{2}$ történt, melynek $330 \mu \mathrm{m}$ a szemnagysága. Egy svéd kísérlet kimutatta: $450 \mu \mathrm{m}$ helyett $80 \mu \mathrm{m}$ érzékenységü hálót használva 100 000-szer nagyobb mikroplasztikum koncentrációt lehet mérni. Tehát nagyságrendekkel nagyobb lehet a valódi szennyezettség. A feldarabolódás gyorsabb ütemben zajlik az északatlanti térségben, mint gondoltuk (Cole et al. 2011).

Kiderült az is, hogy a három vizsgált felhalmozódási zóna közül kettőből, az Észak- és Dél-Atlanti-zónából még van esélye kikerülni a múanyagoknak, azonban a Dél-Csendes-óceán szubtrópusi örvénye hosszú időre csapdázza őket, míg le nem ülepednek. Elképzelhetö, hogy az Egyenlítőn is átjutnak a plasztikumok: Ecuador és Indonézia partjai mentén a határáramlatokkal. A Csendes-óceán északi részéről délre vándorolhat a szemét és vice versa egészen Hawaii partjáig. Az Antarktisz körüli vizekben is megjelent már a müanyagszennyezés, feltehetően a déli áramlatok és a hajóforgalom miatt (Eriksen et al. 2013).

\section{Felhalmozódás tengerpartokon}

A tengerpartok elszennyeződését a turizmus, a terjeszkedő települések és az ipari tevékenység mellett egyre inkább az óceán felől érkező szemét okozza. Az óceánokba juttatott mủanyag szemét egy része visszatér a tengerpartokra az áramlás zavarai, a helyi áramlási és szélviszonyok, a földrajzi környezet sajátosságai, valamint az időjárás változékonysága miatt.

Panama megtisztította partjait a 90-es években, de 3 hónap múlva ismét megjelent a szemét, méghozzá az eltakarított mennyiség fele. Dél-Afrika partjai is évről évre szemetesebbé válnak (Derraik 2002).

Chilében rendszeresen szerveznek parttisztításokat, de ott döntően helyi eredetủ a szemét (hajózás, halászat, akvakultúrák, helyi strandolók, turisták), mivel a dél-csendes-óceáni-örvény összegyüjtő hatása igen erős. Több szemét érkezik viszont az óceán felől Brazíliába, Ausztráliába vagy Japánba. Évente körülbelül 250 hulladék darab éri el 100 méterenként a tengerpartokat az észak- és dél-atlanti régióban. A zárt tengerek esetén, például a Mediterrán térségben még nagyobb intenzitású a partra mosódás. Belgiumban a száraz tengerparti üledékben háromszorosára nőtt a mikroplasztikumok mennyisége: 55 db/kg-ról (1990-es évek) 156 db/kg-ra (2000-es évek) (Cole et al. 2011).

2 Hasonlít a háló alakja az ördögrájáéra, ami latinul Manta, innen az elnevezés. 


\section{Felhalmozódás tengerfenéken}

A 90-es évek óta vizsgálják a kutatók ezt a kérdést. Azóta minden óceán- és tengerfenéken találtak mủanyagot. Mivel a szemcsék lebegnek vagy úsznak, lesülylyedésük biológiai aktivitásnak köszönhető: benövik őket a mikroorganizmusok vagy bekerülnek a tengeri élölények szervezetébe és tetemükkel együtt jutnak le az aljzatra. A folyók hordalékával a kontinentális self területeken is leülepedhetnek: például Brazília partközeli tengeraljzatán sokkal több a müanyag, mint tengerpartján. Nagy sürüséget mértek tengerparti kanyonokban is (akár 112 hulladék darab/km, ennek $70 \%$-a mủanyag). Egy arktiszi merülés során több ezer méter mélységben is láttak néhány mủanyag darabot, amit a norvég áramlás szállíthatott oda az észak-atlanti térségből. A Tokiói-öböl alján a mesterséges objektumok 8085\%-a műanyag. Európa partjai mentén a Földközi-tenger aljzatán legnagyobb a müanyagok sürüsége: elérheti a $100000 \mathrm{db} / \mathrm{km}^{2}$ értéket is, ami hasonló nagyságrendủ, mint az óceáni hulladékszigetekben (Barnes et al. 2009).

\section{Felhalmozódás szigeteken}

Az áramlás időszakos változásai nemcsak a tengerpartokra sodorják vissza a szemetet, hanem távoli óceáni szigetek partjaira is. Sok esetben ezek lesznek a végső felhalmozódási zónák (Moore et al. 2001).

Hawaii szigetén, a Kamilo nevezetü 15 km-es partszakaszon önkéntesek évente 16 tonna hulladékot gyüjtenek össze. Úgy is nevezik: a Szemetes-part. Az ide kerülő mủanyag szemét elhagyott halászeszközökből, vegyes nagyobb darabokból és nagy koncentrációjú PE és PP darabokból áll. Többségük nem a környező szigetekről származik, hanem idegen eredetü: vagy a helyiek nem használnak hasonló terméket, vagy külföldi nyelvű címkékből, jelölésekből és logókból lehet erre következtetni. A modellek szerint az észak-csendes-óceáni hulladékszigetről származnak. Ha az áramlások állandóak lennének, akkor egy foltban maradnának a mủanyagok az örvényzónában, de a hidrodinamikai anomáliák kilökik és felhalmozzák őket Kamilo partjain (Carson et al. 2012).

Hasonló jelenség játszódik le más óceáni szigeteken. A korábban említett 2013as dél-csendes-óceáni expedíció végállomása a Húsvét-sziget volt. Ez a világ legelszigeteltebb lakható földterülete (2100 km-re fekszik a legközelebbi sziget). Öslakói előrelátás nélkül aknázták ki természeti erőforrásait, kultúrájuk összeomlott. A szigetről eltűntek a fák, a madarak és a virágok. A megmaradt néhány lakos megpróbálja visszaállítani a talaj termőképességét és fenntartható életvitelt folytatni. A szigetet napjainkban újabb veszély fenyegeti: partjainál elkezdett felgyülni az óceáni szemét. Homokos partszakaszait elborították a színes múanyag darabok milliói, melyek a közeli hulladékfoltból származnak (Eriksen et al. 2013). 
A Hawaii-hoz és Chiléhez hasonló izolált óceán-közepi szigetek természetes hálóként müködve gyüjtik be a hulladékörvényekből a szennyeződéseket. Reális veszély, hogy a Föld óceánjainak minden szigete szemétteleppé válik.

\section{Kémiai hatás}

Az óceánok mủanyaggal történő elszennyezése nem csak esztétikai problémát okoz. Kiderült, hogy a felaprózódás közben felszabadulnak a veszélyes adalékanyagok, továbbá a tengerekben kis mennyiségben jelen lévő szerves szennyeződéseket is megkötik, ezzel akár milliószorosára feldúsítva a koncentrációt. Végleg eloszlott az a tévhit, hogy a mủanyagok tiszták és biztonságosak. A kémiai hatás részletei következnek.

\section{Szerves szennyezödések az óceánokban}

Az óceánokban és tengerekben kis koncentrációban jelen lévő antropogén szerves szennyeződéseket több névvel is illetik: POPs (Persistent Organic Pollutants), HOCs (Hydrophobic Organic Compounds) vagy még pontosabban PBTs (Persistent Bioaccumulative and Toxic substances).

Négy fő tulajdonságuk van: nehezen bomlanak, mérgezőek, élőlényekben felhalmozódnak és víztaszítók. Nehezen bomlanak le, mert stabil, ellenálló vegyületek. Ártalmasak, mert magzatkárosítók, megnövelik a mutációk gyakoriságát és rákkeltők, károsítják a hormonrendszert. Felhalmozódnak az élőlények szervezetében és a táplálékláncban is. Vízben nem oldódnak, a műanyag szemcsék felületéhez viszont könnyen hozzátapadnak (Kershaw et al. 2011).

A POP vegyületcsalád tagjai a környezetbe kerülhetnek mezőgazdasági használat során: növényvédő szerek és rovarölő szerek (pl. DDT és HCH-k) szétpermetezésével. Ipari tevékenység, szén-, olaj- és földgázégetés is lehet a forrásuk (pl. dioxinok és PAH). Kikerülhetnek mesterséges objektumokból is: transzformátorok hủtő-szigetelő vagy hidraulikus rendszerek hőátadó folyadékából (PCB-k), elektronikai eszközökből (égésgátló anyagok), valamint építő-anyagokból (PBDE-k). Veszélyességüket jelzi, hogy használatukat szigorúan korlátozzák és felügyelik, többet be is tiltottak közülük a nyugati országokban a 20. század második felében. Ennek ellenére a DDT-t malária ellen máig használják több országban, például Vietnamban, Costa Ricában, Indiában és Dél-Afrikában. Ezen POP vegyületek az esővízzel, folyókkal és felszíni lefolyással a tengerekbe jutnak (Hirai et al. 2011). 
Szerves szennyezödések felületi megkötödése

A PBT vegyületeket a mikroplasztikumok nagyobb koncentrációban kötik meg felületükön, mint más oldott részecskék, derült ki egy 2001-es japán vizsgálatból (Mato et al. 2001). A Tokiói-öbölben PP ipari mügyanta szemcsék PCB és DDE 3 adszorbeáló képességét vizsgálták. A PP szemcsék felületi megkötődési együtthatója $10^{5}-10^{6}$ értékünek bizonyult. Gyakorlatilag ez azt jelenti, hogy a szemcsék képesek 100 000-szer vagy 1000 000-szor nagyobb mértéküre dúsítani a szennyező anyagok koncentrációját. Ennek egyik oka erősen víztaszító felületük. Telített szénhidrogén egységekből épülnek fel, felszínük nem poláris. Kiválóan alkalmas arra, hogy a PCB-hez és DDT-hez hasonló víztaszító szennyeződéseket megkösse. Másrészről a PP szemcsék kis sürüségük miatt a víz felszínén lebegnek, pontosan ott, ahol feldúsulnak ezek a vegyületek. A PBT vegyületekkel túltelített víz-levegö határfelületi mikrorétegben igen hatékonyan tud végbemenni a felületi megkötődés. Kísérletet is végeztek a japánok: 6 napra kihelyeztek hasonló szemcséket az öböl vizére és a megkötés sebessége alapján arra következtettek, hogy néhány év alatt elérheti a szennyezettség ezt a magas koncentráció értéket. Ez több tényezőtől függ: a felület bomlása, roncsolódása segíti a megkötést, a több üreg, repedés növeli a kötőhelyek számát, ugyanakkor az oxigén-tartalmú molekula csoportok szabaddá válása csökkenti a hozzátapadás erősségét.

Egy másik tanulmány a $\mathrm{PAH}$ vegyületek megkötődését vizsgálta mügyanta szemcséken. A PE és PS szemcsék magasabb koncentrációban kötötték meg a víztaszító polimereket, mint a PP, PET, PVC anyagúak (Rochman et al. 2013).

Ugyanakkor a müanyagok nemcsak kötőhelyei, de forrásai is lehetnek a szenynyeződéseknek. Feldarabolódás közben felszabadulnak belölük a gyártás során hozzáadott adalékanyagok: stabilizátorok, lágyítók (ftalátok), égésgátlók (PBDE vegyületek), baktériumölök, kiindulási anyagok (pl. Biszfenol A), vagy az óceánig tartó transzport során a szennyvízből megkötött anyagok: például nonil-fenolok (mosószer-előanyagok, idegen ösztrogének) vagy a triklozán (fertőtlenítőszer). Az így kibocsátott anyagok veszélyessége különböző: biológiai lebomlásra mérsékelten képesek (Biszfenol A), kis mértékben felhalmozódnak (ftalátok, nonifenolok) vagy bomlásnak erősen ellenállóak (pl. égésgátlók). Legnagyobb veszélyt a halakra és az őket elfogyasztó emberekre jelentik. Fontos észrevétel, hogy a müanyagok bomlása során kiszabaduló káros anyagok a keletkező kisebb szemcsék felületén ugyanolyan mechanizmussal adszorbeálódhatnak, mint a már jelen lévő szennyeződések (Engler 2012).

A felhasználói mủanyag darabok megkötő-képessége hasonló, mint az ipari szemcséké. Az észak-csendes-óceáni térség több részéröl gyüjtöttek mintákat: urbanizált és lakatlan tengerpartokról, valamint a nyílt óceánról. A helyszíneket

3 A DDE a DDT egyik bomlásterméke, szintén veszélyes anyag. 
tekintve: Vietnam, Japán, Kalifornia, Costa Rica partjairól és a hulladékörvény közepéről. Kiegészült még az elemzés egy észak-atlanti-óceáni mintával is a Karib-tengerről. A legnagyobb károsanyag-koncentrációkat (PCB, DDT, PBDE, BPA) a városokhoz közeli partszakaszokon mérték. Ennél kisebb volt a nyílt óceánról és távoli partokról származó minták vegyi anyag tartalma. Kimutatták, hogy az aprózódás során felszabaduló szennyeződések mellett a levegőből vízbe kerülö szennyeződéseket is megkötötték a szemcsék. Összhangban a hasonló kutatásokkal, a PE típusú szemcsék szorpciós képessége nagyobbnak bizonyult, mint a PP összetételüeké. Ami a leglényegesebb eredmény: szoros korrelációt mutattak ki a felaprózódott fogyasztói mủanyagok és az eredendően kis méretű ipari plasztikszemcsék adszorbeáló képessége között. Mindkét típusú müanyag egyformán veszélyes (Hirai et al. 2011).

Bebizonyosodott, hogy a müanyag darabok jó indikátorai a partok állapotának: minél nagyobb a felszínükön mérhető szennyezőanyag koncentráció, annál szennyezettebbek a környező vizek, a tengerpartok és az üledékek. Egy globális felmérés eredményeképp 2009-ben (Ogata et al. 2009) térkép készült a világ tengerpartjainak szennyezettségéről, melyet később további helyszínekkel bővítettek ki. Hat kontinens 29 országának 56 partjáról vettek mintákat és határozták meg PCB tartalmukat. Az eredményeket egy világtérképen összegezték (Kershaw et al. 2011).

A legmagasabb értékeket a centrum országok (USA, Ny-Európa és Japán) partjai mentén mérték. Az iparosodott országok az 1960-as és 1970-es évek gyors gazdasági növekedése során rengeteg PCB-t használtak; például az USA hasznosította a világon előállított PCB mennyiség több mint felét. Hiába tiltották be később, mivel perzisztensek, máig jelen vannak a tengervízben és felhalmozódnak a tengerparti üledékben. Ázsiában két nagy feltörekvő ország, India és Kína vizeinek szennyezettsége mellett a Fülöp-szigeteké is kiugró. Dél-Afrika partjai tekinthetők a legtisztábbnak: a 80-as évek gazdasági növekedésében nélkülözte a PCB használatát, később a tilalom miatt nem is lett volna rá lehetősége (itt viszont a HCH érték kiugróan magas a rovarirtószerek használata miatt). Az adatokból kiolvasható, hogy lineáris összefüggés van az ipari fejlettség és a vizek szennyezettsége között (Kershaw et al. 2011).

\section{Biológiai hatás}

A makro méretủ műanyagok fizikailag károsítják a tengeri élőlényeket: külsejüket megsértve, emésztőrendszerüket eltömítve vagy belegabalyodással megölve őket. A mikro méretűek pedig megmérgezik őket: a szemcsékkel együtt szervezetükbe 
jutnak a felületükön koncentrált vegyi anyagok is. Tehát kijelenthetö, hogy a müanyagok kiemelkedő veszélyforrást jelentenek a tengeri élővilágra. Sorra veszem a legfontosabbakat.

\section{Halálos nyaklánc és szellemhalászat}

Több mint 267 nagytestü állatfajról írták le már az 1990-es években, hogy a nagyobb méretü mủanyag objektumok károsítják őket külsőleg vagy belsőleg, a táplálkozás során szervezetükbe kerülve (Moore 2008). Néhány példa közülük: teknösök, pingvinek, albatroszok, viharmadarak, rablósirályok, sirályok, alkák, parti madarak, bálnák, delfinek, valódi fókák, oroszlánfókák, medvefókák, tengeritehenek (manátik és dugongok), cápák, tengeri vidrák, halak és rákok. Még szemléletesebb az összesített adat: a tengeri teknősfajok $86 \%$-a, a tengeri madárfajok 44\%-a és a tengeri emlősök $43 \%$-a potenciálisan veszélyeztetett a múanyagok által. Mindez valószínüleg erősen alábecsült, mert minden bizonnyal a legtöbb áldozatot nem fedezzük fel a hatalmas óceáni területeken: lesüllyednek vagy megeszik őket a ragadozók (Derraik 2002). A tengeri élölények belegabalyodhatnak a sodródó hálókba, kötelekbe, horgász-zsinórokba. Több beszámoló szerint a fiatal medvefókák kifejezetten érdeklődnek a műanyag csomagolási hurkok iránt, melyek játék közben testükre tekerednek, olyan szorosan, hogy a húsukba vágnak, végül megfojtják őket: halálos nyakláncnak nevezik a kutatók ezt a jelenséget. Tragikus, hogy amint meghalt a fóka és teteme elbomlott, újabb áldozatokat szedhet ugyanez a hurok. 500 évig is eltarthat a lebomlása, addig sorozatgyilkosként szedi áldozatait (Derraik 2002).

A magára hagyott vagy elvesztett müanyag halászhálók és horgászzsinórok továbbra is betöltik eredeti funkciójukat: hónapokon, éveken át elkapják és megölik a tengeri állatokat. Teknősök, halak, madarak, fókák esnek áldozataul ennek az úgynevezett szellemhalászatnak (Wurpel et al. 2011). Az Élelmezési és Mezőgazdasági Világszervezet (FAO) 1991-es jelentésében úgy becsülte, hogy a halászati eszközök 10\%-a elveszik, ami 10\%-os csökkenést idéz elő a kifogni kívánt halpopulációban (idézi: Moore 2008). Az Új-Zéland és Antarktisz között évente vándorló hosszúszárnyú bálnák vastag köteleket húznak maguk után, melyektől nem tudnak megszabadulni. A tengerfenékre lesüllyedő, sodródó hálók károsítják az ottani élőhelyeket, főleg a korallszirteket, mintegy leradírozva azokat: a korallokba és aljzati növényekbe gabalyodó, áramlatokkal sodródó hálók letörik és kiszakítják helyükről a gazdag élővilágnak otthont adó élőhelyeket, csupasz síkságot hagyva maguk után. Olyan ez, mint az erdei tarvágás (Gregory 2009).

Érdekes megfigyelés, hogy több ezer méteres mélységben fehér müanyag zacskók fejjel lefelé lebegnek és szabadon sodródnak, mintegy szellem benyomását keltve a mélytengerekben. Az ehhez hasonló müanyag darabok gyakran megté- 
vesztik a teknősöket, és a táplálékul szolgáló medúzák helyett ezeket eszik meg, aminek következménye a fulladás vagy bélelzáródás következtében beálló halál. A mủanyag szeméttel való találkozás gyakran okoz maradandó vagy akár halálos sérüléseket is: gennyedző sebeket, fekélyes bőrt, elhalt végtagokat. A tengeri müanyag szemét tehát nagymértékben rontja az élőlények életminőségét és növeli halálozásukat (Gregory 2009).

\section{Mérgezö hatás és felhalmozódás élölényekben}

Kétféleképpen mérgezhetik meg a tengeri élölényeket a szervezetükbe jutott müanyagok. Az emésztő szervrendszerükben savakkal, enzimekkel kapcsolatba lépve bomlani kezdenek és felszabadulnak a veszélyes adalékanyagok. Ezzel egyidejüleg a felületükön megkötött PBT vegyületek deszorbeálódnak. Minden szervet, szövetet károsíthatnak: megzavarják a hormonrendszert, mutagének, karcinogének.

Azon optimista véleményeket, hogy a lenyelt szemcsék gyorsan kiürülnek a kiválasztással és nem okoznak súlyos károsodást egy kékkagylókkal (Mytilus edulis Linnaeus, 1758) végzett német kutatás cáfolta meg (von Moos et al. 2012). A mikrométeres $(0-80 \mu \mathrm{m})$ mủanyag szemcséket a táplálékkal együtt felvették, kopoltyúikkal kiszürték a vízből. A gyomorból felszívódtak és az emésztőmirigyekhez vándoroltak, ahol a sejtekben halmozódtak fel. Tehát az emésztés után nem távoztak el a szervezetükből, hanem szöveteikben feldúsultak: ehhez elég volt 3 óra vizsgálati idő. Szövettani vizsgálatokkal alátámasztották, hogy a sejtekbe kerülve gyulladásos folyamatokat indítottak el. Sőt, képesek voltak már a kopoltyúüregben bejutni a sejtekbe. A mérgező hatás a következőképp nyilvánult meg: a müanyag szemcsék és a belölük felszabaduló mérgek olyannyira roncsolták a sejteket, hogy önlebontó folyamatokat indítottak el, ami szövetelhaláshoz vezetett. A mikroplasztikumok tehát fizikai és kémiai úton is károsították a kékkagylókat. A természetben még erősebb lehet ez a hatás, mert a laborban tiszta müanyag szemcséket használtak, a tengervízben viszont felszínükön POP vegyületeket is koncentrálnak. A kutatók „trójai ló” hatásnak nevezik, amikor a kisméretü plasztikumok bejuttatják az élőlények szervezetébe a veszélyes kémiai anyagokat (Cole et al. 2011).

Az állati szövetekben való felhalmozódás kimutatható szinte az összes tengeri élőlénynél: planktonikus szervezetekben (zooplankton, nyílférgek, halivadékok, evezőlábú rákok, krillek, zsákállatok), gerinctelenekben (tengeri férgek, tengeri rákok, tüskésbőrüek, mohaállatok, kagylók) és gerincesekben (fókák, madarak, delfinek, bálnák). Mindez negatívan hat egészségi állapotukra, rontja túlélési és szaporodási esélyeiket. Kisméretü élőlényekre a mikroplasztikumok, míg na- 
gyobb termetüekre a mikro- és makroplasztikumok egyaránt veszélyt jelentenek (Cole et al. 2013).

A tengeri ökológiai rendszerek állapotának monitorozásához gyakran használják a tengeri madarakat (Ryan et al. 2009). Hatékonyan felmérhető velük a környezet állapota, mert nagy területeket járnak be, a tápláléklánc több szintjéről fogyasztanak élőlényeket és a kolóniákban egyszerre nagy számban vizsgálhatók. Ilyen madár az északi sirályhojsza (Fulmarus glacialis (Linnaeus, 1761)). Vándorlása során bejárja szinte az egész északi féltekét. Az Atlanti- és Csendes-óceán északi partjainál költ. Egy 2003-2007 közötti kutatásban 1295 sirályhojszát vizsgáltak meg és 95\%-uk gyomrában találtak mủanyagokat, átlagosan 35 darabot, 0,31 g tömeggel (Van Franeker et al. 2011). Az 1980-as évektöl figyelik őket, s ez az arány mindig $90 \%$ felett volt. Ennek oka, hogy a táplálékuk és a müanyagok egyazon területen dúsulnak fel: az óceánok felszínén. A levegőből könnyen összetévesztik természetes táplálékukat a vízen lebegő, hasonló formájú és színú müanyagokkal. A sirályhojszák esete nem egyedi. Több mint 100 tengeri madárfajról tudják a kutatók, hogy müanyag darabokat halmoznak fel a gyomrukban (Gregory 2009).

\section{Biológiai nemváltozás és kiszáradás}

A mủanyagok jelenléte a tengerpartokon drámaian megváltoztatja a homokos üledék fizikai-kémiai tulajdonságait. Ezt egy Hawaii-on végzett vizsgálat derítette ki. A hőelnyelő képessége lecsökkent a plasztikszemcsés-homokos üledéknek, ami azt jelenti, hogy kevésbé tud felmelegedni napsütéses időben. Ez kihathat a tengeri teknősök ivararányára: a tojásokból kikelő teknősök nemét a környező hőmérséklet határozza meg. Magasabb hőmérsékleten nőstények, alacsonyabban hímek születnek. Amennyiben lehül környezetük, megnövekszik a hím egyedek aránya, ami veszélybe sodorhatja a fennmaradásukat. Ezzel szemben az áteresztőképességet növelik a müanyag szemcsék, így a nedvességmegtartó képesség csökken, ami az üledéklakó élőlények kiszáradását okozhatja, például árapálykor (Cole et al. 2011).

\section{Ökológiai hatás}

Az élőlénytársulások kétféle veszélynek vannak kitéve. Egyrészről a mindenhova eljutó müanyagok felületén agresszív, inváziós fajok érkezhetnek a különféle tengeri élőhelyekre, így kiszorítják a helyi fajokat, csökkentik a biológiai sokféleséget. Másrészről az élőlényekben feldúsult műanyag szemcsék a táplálékláncban horizontálisan és vertikálisan haladva szétterjednek: minden tengeri élőlény szervezetébe bejuthatnak. A következőkben e hatásokat fejtem ki részletesen. 


\section{Invaziv fajok terjedése}

A tengerben sodródó törmelékkel korábban is eljutottak különböző fajok távolabbi helyekre. A természetes tengeri szállítórendszert leggyakrabban lebegő hínárok, habkövek (porózus, vízen úszó vulkanikus kőzet) és fadarabok alkotják. Ez eddig egy lassú és erősen korlátozott folyamat volt: a szállító anyagból viszonylag kevés fordult elő, illetve hamar lebomlott vagy táplálék lett belőle. A müanyagok megjelenése teljesen megváltoztatta ezt a helyzetet. Nagy mennyiségük és ellenálló, stabil felületük szinte korlátlan lehetőséget teremtett az opportunista ${ }^{4}$ kolonizáló fajok szétterjedése előtt. Az utazások gyakoribbá és hosszabb idejüvé váltak, nagyobb távolságokat lehetett leküzdeni (Barnes 2002). Lényegét tekintve tehát felgyorsult az idegen, gyakran invazív fajok világméretü diszperziója. Mindez komoly veszélyt jelent a biodiverzitásra nézve. A megjelenő új fajoknak nincs, vagy csak kevés a természetes ellensége, a zsákmányállatok és paraziták nem ismerik fel öket a koevolúcó hiánya miatt. A helyi ökoszisztéma nem tud hatékonyan védekezni ellenük: ez teszi lehetővé hirtelen és tömeges elszaporodásukat. Becslések szerint 58\%-al csökkenne a globális tengeri fajgazdagság, ha megvalósulna az élőlények teljes keveredése (Derraik 2002).

A lebegő müanyag objektumokon (bójákkal, kötelekkel) vagy a mikroplasztikumokon bevonatot képezve baktériumok, kovamoszatok, algák, zsákállatok, hidraállatok, mohaállatok, tengeri makkok (apró rákfélék), kagylók, tengeri csigák, tengeri csőférgek és eukarióta egysejtűek juthatnak el olyan élöhelyekre, melyen azelőtt sose fordultak elő. Tengerpartok, árapály zónák, sekély tengerek és távoli óceáni szigetek sérülékeny ökológiai rendszereire nézve jelenti a legnagyobb fenyegetést az invazívvá váló idegenhonos fajok megjelenése (Gregory 2009).

Néhány konkrét esetet is dokumentáltak. Egy mohaállat (Membranipora tuberculata (Bosc, 1802)) átszelve a Tasmán-tengert Ausztráliából Új-Zélandra jutott mügyanta-szemcséken utazva. Egy másik mohaállat (Electra tenella (Hincks, 1880)) a Karib-tengerről érkezett az USA partjaihoz müanyag darabokon. Leírták azt is, hogy tengeri makkok egy csoportja múanyagokhoz tapadva átszelte az egész Atlanti-óceánt (Derraik 2002).

A veszélyt tovább fokozza, hogy egy-egy müanyag szemcsén nemcsak néhány élőlény, hanem több száz különféle faj is előfordulhat, melyekből több is veszélyes lehet. Az Észak-Atlanti-óceán szubtrópusi örvényéből vett PP és PE szemcséket megvizsgálva gazdag mikrobiális élővilágot fedeztek fel, melyet a kutatók plasztikszférának neveztek el (Zettler et al. 2013). Találtak fényhasznosító, szerves anyagot fogyasztó, bekebelező, együttélő és kórokozó baktériumokat is, vagyis egy egész kis közösséget. Mintát vettek a környező tengervízből is, hogy

4 Olyan fajok, amelyek a változékony környezetek elviseléséhez alkalmazkodtak, és jellemzően gyors a növekedéseük és a terjedési sebességük. 


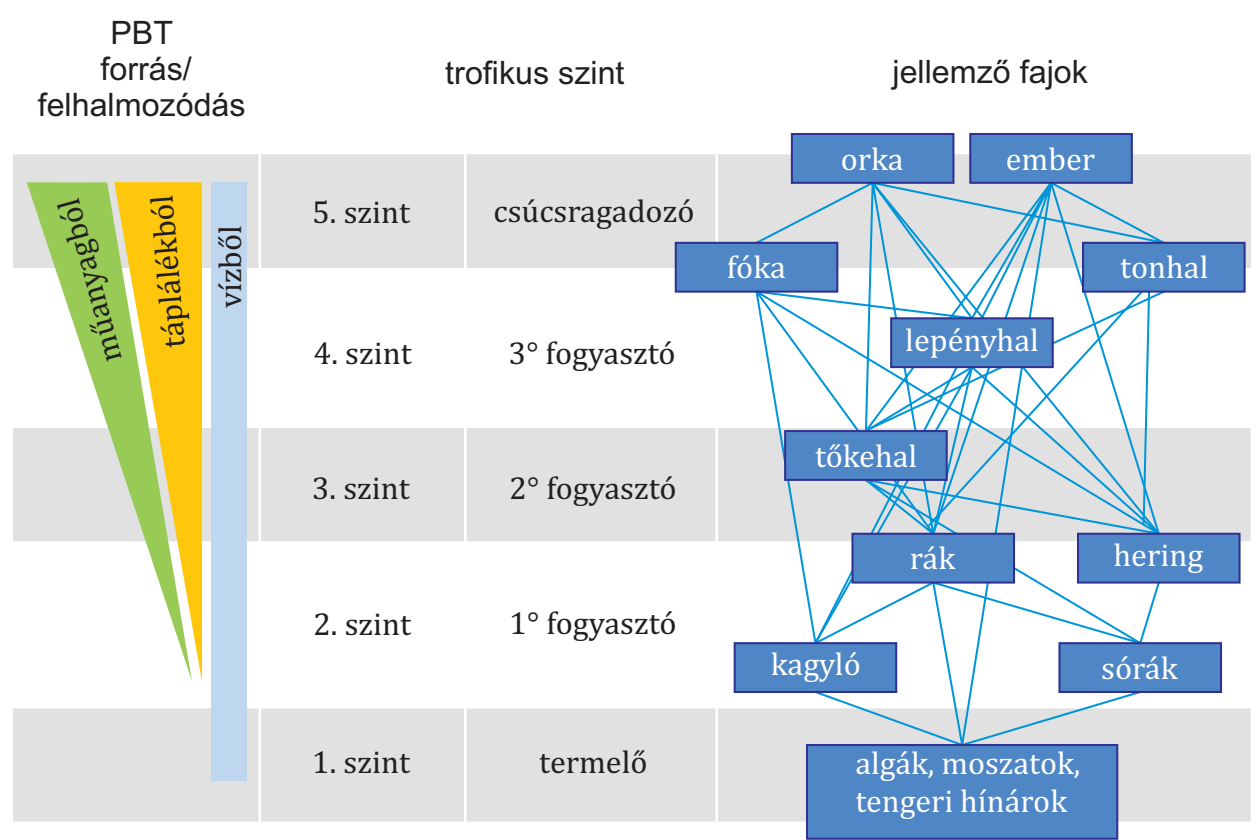

2. ábra. A PBT vegyületek három forrásból eredő felhalmozódása egy ötszintü tengeri táplálékhálóban (ábra forrás: Engler 2012).

összehasonlítsák a diverzitási mintázatokat. Két lényeges különbség vehető észre. A környező vízben sokkal magasabb volt a fajgazdagság, de a müanyag szemcsék élővilága ettől alapvetően eltért, viszont ezek egymással nagy hasonlóságot mutattak. Egyértelmủen látszik, hogy távolról utaztak ide a szemcsék, nem helyben történt meg a kolonizáció, és vannak olyan biofilm alkotó baktériumok, melyeknek ideális élőhelyet jelent ez az új környezet. Egy új ökológiai fülke jött létre.

Az idegenhonos fajok földkörüli elterjedéséhez tehát minden feltétel adott. Egyedül az Arktisz és Antarktisz élvez védettséget: a 60. szélességi fok felett mủanyagokon nem figyelhető meg fauna. Az alacsony hőmérséklet és a magasabb UV-sugárzás nem kedvez a vándoroknak. Ez azonban nem lesz sokáig így. A legvalószínűbb modell szerint a század közepére regenerálódik az ózonpajzs az ózonfaló vegyületek használatának korlátozása miatt, a globális éghajlatváltozás következtében pedig a számítások szerint több mint $2{ }^{\circ} \mathrm{C}$-ot nő a hömérséklet a Déli-Óceán térségében. Az Antarktisz körüli vizek 25 millió éve jól el vannak szigetelve a környező vizektől a cirkumpoláris áramlattal ${ }^{5}$, így nagyon sok őshonos faj otthonát képezik. Ha a térségben már felfedezett múanyag szemcsék mellett

5 Az óramutató járásával megegyező irányban forgó, Ny-ról K-re örvénylő víztömegek. 
megjelennek az idegen fajok is, az drámaian károsítani fogja a térség ökológiai rendszerét (Barnes 2002).

\section{Felhalmozódás táplálékláncban}

A PBT-k táplálékláncban történő felhalmozódása három forrásból ered: magából az életközegből (tengervízből), az elfogyasztott élelemböl (szürögetés, predáció, dögevés) és a szervezetbe került múanyag darabokból. A folyamat jól szemléltethető egy jellegzetes tengeri hálózat elemzésével (2. ábra).

Az erőteljesen szennyezett Tokiói-öböl vizében 0,93-1,02 ppb $^{6}$ a PCB háttérkoncentrációja. Minden tengeri élőlény ebben a közegben él. A kopoltyújukon, emésztőrendszerükön vagy szervezetükön átáramló vízből a szöveteikben megkötődik a szennyezés egy része, ez a biokoncentráció jelensége. A táplálékpiramis legalján helyet foglaló elsődleges termelő szervezetekben (algák, moszatok, tengeri hínárok) kialakul egy, a környezetnél magasabb szennyezőanyag koncentráció. Ezen a szinten ez az egyedüli forrás.

Az aljzaton táplálkozó, üledékevő élőlények (férgek, rákok) bélrendszerében a lenyelt homokszemcsékből és parányi műanyag szemcsékből mobilizálódnak a megkötött méreganyagok. Hasonló a helyzet a szürögető módon táplálkozó kagylókkal és tengeri uborkákkal. A táplálékszemcsék mellett müanyag szemcséket is felvesznek, melyek hetekig, hónapokig a szervezetükben maradnak, eközben kioldódnak a káros anyagok. A lebegő életmódot folytató apró termetủ sórákok (Artemia salina (Linnaeus, 1758)) a fotoszintetizáló szervezetek elfogyasztásával jutnak hozzá ezekhez a vegyületekhez. A táplálékpiramis második szintjén tehát két új forrás jelenik meg: az elfogyasztott élelem és a mủanyag szemcsék. Ez a folyamat a bioakkumuláció.

Ahogy haladunk felfelé a táplálékpiramisban, úgy növekszik a táplálékkal és müanyagokkal bejuttatott PBT mennyiség, a vízből történő közvetlen adszorpció viszont egyre kevésbé lesz meghatározó. Az élőlények mérete növekszik, számuk viszont csökken. A több zsírszövet több víztaszító vegyületet képes megkötni. A biomagnifikáció során minden szintlépéskor egy nagyságrenddel növekszik a szervezetben felhalmozott mennyiség, amit egy japán vizsgálat is kimutatott. Az átlagos PCB koncentráció növekedése a következő volt: tengervízben 0,98 ppb, tengeri csigákban 48 ppb rákokban és halakban 240 ppb. Az USA atlanti-óceáni partvidékén lepényhalakban (2-3. szint között) 1000-6000 ppb értéket mértek (hozzá kell tenni, hogy egy fokozottan szennyezett területről van szó). Ez még csak a tápláléklánc közepe. A felhalmozódás könnyen észrevehető, ahogy szintről szintre haladunk felfelé. Egy 3-4. szint közötti tőkehal korábban ehetett olyan tarisznyarákokat és heringeket a 2-3. szintről, melyek kagylókat és sórákokat fo-

$6 \mathrm{PPB}=$ parts per billion $=\mathrm{db} / \mathrm{mrd}=\mu \mathrm{g} / \mathrm{l}=\mathrm{ng} / \mathrm{g}$ 
gyaszthattak az 1-2. szintről, ezek pedig algákból és hínárokból lakhattak jól. Így a plasztikszemcsék a táplálékból vagy a táplálékkal együtt jutnak egyre feljebb és feljebb a 2. szinttől kezdve.

A 4-5. szint között (a tápláléklánc magasabb szintjein) megjelennek a gerincesek. Tengeri teknősökben és tojásaikban is magas a szennyeződés mértéke. A fókák zsírszövetében 1370 ppb PCB felhalmozódást találtak. 13 megvizsgált tengeri madárfaj 30 egyede közül volt, amelyikben 10000 ppb-nél is többet mértek. Megállapították, hogy ez elsősorban nem a halfogyasztásból származik, ugyanis gyakran csipegetnek fel számukra vonzó, vízen lebegő, színes müanyag darabokat. Egy gramm müanyagból hatszor több PCB oldódik ki bélrendszerükben, mint az egy napon megevett halmennyiségből. Ez világosan megmutatja, hogy kis mennyiségü lenyelt szennyezett műanyag is jelentős veszélyt jelent rájuk nézve. Egyes fajokat tekintve tehát nagyobb a közvetlen, mint a közvetett PBT felhalmozás. Nagyobb fenyegetettségnek vannak kitéve azok a madarak, melyek olyan területek felett repülnek, ahol magasabb a vízen lebegö müanyag darabok PCB koncentrációja (néhány ilyen térség: ÉK-USA, New-England (max. 5000 ppb), Japán (max. 2300 ppb), Észak-Csendes-óceán (max. 980 ppb), Észak-Atlanti-óceán (300-600 ppb), Dél-Csendes-óceán, Brazília (243-491 ppb). A kutatók azonban tudják, hogy egy-egy kiugró koncentrációjú szemcse bárhol felbukkanhat, hiszen könnyen átszelhetik az óceánokat. Gyakorlatilag nincs biztonságban egyetlen tengeri madár sem. A tengerek csúcsragadózóiban, a kardszárnyú delfinekben - más néven orkákban - közel 1000000 ppb értékeket mértek (Engler 2012).

Megvizsgálva a teljes láncolatot tehát drámai mértékü feldúsulást lehet tapasztalni: a kezdeti, 1 ng/g nagyságrendröl (1. szint) $1000000 \mathrm{ng} / \mathrm{g}(1 \mathrm{mg} / \mathrm{g})$ nagyságrendre (5. szint) nőtt az élőlényekben koncentrálódott PBT vegyületek mennyisége. Ez hat nagyságrendủ, milliószoros dúsulást jelent. A tengeri eredetủ élelmek fogyasztása ezért válik egyre veszélyesebbé, főként a szennyezettebb vizekben halászó szegényebb országok halászai számára.

\section{Az emberi egészségre kifejtett hatás}

A tengeri környezet müanyag szennyezése az ember egészségére is potenciális, közvetett veszélyforrást jelent, ugyanis az ember többféle tengeri élőlényt fogyaszt a táplálékpiramis magasabb szintjeiről - föképpen halakat, kagylókat és rákokat -, melyek közvetítésével visszajutnak szervezetünkbe a korábban szenynyezésként kibocsátott, és a tengeri élőlényekben felhalmozódott méreganyagok.

A POP vegyületcsalád tagjai (PCB, PBDE, PAH, DDT, DDE, HCH és egyéb PBT vegyületek) egyértelmü mutagénnek és karcinogénnek bizonyultak állatkí- 
sérletekben (egerek, patkányok, rhesus majmok), és ez a hatás valószínüsíthető emberekben is. Testidegen anyagok - szerkezetük a hormonokéhoz hasonlít (xenoösztrögének) -, így képesek megzavarni a hormonális rendszer múködését (endokrin diszruptorok). Csökkentik a nők és a férfiak termékenységét, csecsemőknél születési és fejlődési rendellenességet okozhatnak. Mérgező hatásukat szintén állatkísérletek támasztják alá: májkárosítók és idegrendszer károsítók (Faroon et al. 2002).

Japánban 2005-ben megjelent egy epidemiológiai tanulmány, mely összegezte a PCB-k egészségre gyakorolt hatásait (Arisawa et al. 2005). A poliklórozottbifenilek - hasonlóan a PBT vegyületcsalád többi tagjához - xenobiotikumok, szervezetidegen anyagok, fokozottan károsak az egészségre. Hiába tiltották be, illetve korlátozták használatukat a hetvenes évektől kezdve, mivel nehezen bomlanak le és zsíroldékonyak, felhalmozódtak, és továbbra is felhalmozódnak a környezetben, valamint az élőlényekben.

Az emberi szervezetbe kerülve tehát tartósan, hosszú időn keresztül fejtik ki hatásukat. Anyagcserezavarokat okoznak, melyek leginkább az idegrendszer müködésének romlását eredményezik. Legnagyobb veszélyben a magzatok vannak. A terhes anyák megnövekedett PCB szintje csökkentette a megszületett csecsemők testsúlyát, lassította növekedésüket és negatívan hatott a mozgási és megismerő képességeik fejlődésére. Ezt a hatást fokozta, ha szoptatás alatt is magas volt az anyukák PCB szintje, ugyanis az anyatejjel is átjutottak a gyerekek szervezetébe (Faroon et al. 2002).

A veszélyes kémiai anyagok mellett káros algamérgek és patogén baktériumok is a szervezetünkbe kerülhetnek tengeri eredetü élelem fogyasztásakor. A mikroplasztikumok felületén mérgező algák is megtelepedhetnek, például dinoflagellata fajok, melyek dinotoxinokat termelnek. Az elsődleges fogyasztó szervezetekbe (kagylókba, rákokba és halakba) kerülve folyamatosan felhalmozódnak ezek az algákban lévő méreganyagok, emberi fogyasztás esetén pedig mérgezési tüneteket is okozhatnak. A felhalmozódás olyan mértékü is lehet, hogy a halak belepusztulhatnak. A müanyag-szemcsék bakteriális élővilágát elemezve emberi kórokozókat is találtak a Vibrio nemzetségből (Zettler et al. 2013). A Vibrio sp. baktériumok gyomor- és bélrendszeri tüneteket, valamint vérmérgezést okoznak.

\section{Társadalmi és gazdasági hatás}

Leginkább a tengerparti közösségeket érintik a tengeri müanyagszennyezés okozta költségek, pedig elsősorban nem ők okozzák a problémát, így nem érvényesül a szennyező fizet elv. A halászat, hajózás, turizmus és akvakultúra gazdasági 
szektorok - melyek munkát és megélhetést adnak több millió embernek - komoly károkat szenvednek el.

A legkézzelfoghatóbb gazdasági hatás a halászati lehetőségek csökkenése. Rengeteg időt és energiát vesz igénybe a halászhálók és hajócsavarok megtisztítása, a hajózhatatlan területek kikerülése. A hálókba nemcsak hal kerül, hanem szemét is, így a fogás egy része elveszik. Mindezt jól mutatja a skót halászok körében végzett felmérés: a halászhajók $86 \%$-ának munkáját korlátozta a tengeri szemét, a fogás $82 \%$-a tartalmazott valamilyen hulladékot, s 95\%-uk halója akadt el valamilyen tengerfenéki mesterséges tárgyban. Mindez a skót halászati iparnak évi 16 millió dollár kárt okoz. Ez 5\% kiesést jelent a halászok jövedelméből. Indonéziában a hálókba akadt müanyag zacskók jelentős mértékben csökkentik a halfogást. Nagy-Britanniában 2008-ban 2,8 millió dolláros költséget jelentett az elakadt propellerü halászhajók kimentése. Figyelembe véve, hogy a világ halászati ipara évi 94 milliárd dolláros forgalommal rendelkezik, több milliárd dolláros a veszteség csak ebben a szektorban (Wurpel et al. 2011). A FAO 1991-es becslése szerint $10 \%$ veszteséget okoz a szellemhalászat a kifogható halállományban, a sodródó halászeszközök eltávolításainak költségei pedig rontják a kereskedelmi halászat jövedelmezőségét.

A homokos tengerpartok megtisztítása óriási költségeket emészt fel. Hollandiában és Belgiumban évi 13,65 millió dollárt kell erre a célra fordítani és ezek a költségek rohamosan nőnek. Nagy-Britanniában az elmúlt 10 évben 38\%-al nőttek a tisztítás költségei: 23,62 millió dollárra. A kaliforniai Long Beach városa 2,2 millió dolláros ráfordítással tudja csak tisztán tartani partját a Csendes-óceánból érkező szemét eltakarításával. Globálisan, a 34 millió kilométernyi tengerpart tisztán tartására a becslések szerint 60 milliárd dollárt kellene költeni évente (Wurpel et al. 2011).

A tengerpartok és partközeli vizek állapotának romlása a turizmust is csökkenti. Ez azokon a helyeken jelenti a legnagyobb gondot, ahol ez az egyik fö bevételi forrás, például az északkelet-kínai kikötővárosban, Dalianban, ahol több tízmillió dollárt kellene ráfordítani a tengerpartok állagmegóvására, hogy továbbra is vonzó legyen a Japánból, Dél-Koreából és Oroszországból érkező turisták számára (STAP 2011).

Az APEC régióban (az Ázsiai és Csendes-óceáni Gazdasági Együttműködés térségében), mely magában foglalja Kínát, USA-t, Kanadát, Mexikót, Oroszországot, Ausztráliát, Új-Zélandot és még másik 14 óceánparti államot, évi 1265 millió dollár kiesést jelent a halászat, hajózás és turizmus iparának visszaesése. Tehát a tengeri hulladék által okozott gazdasági károk már most számottevőek és egyre csak növekednek, újabb és újabb szektorokat érnek el. 
Az idegenhonos fajok terjedése a müanyag felszínén utazva nemcsak a tengeri ökoszisztémákra jelent veszélyt, hanem az akvakultúrákban tenyésztett, gazdasági szempontból jelentős fajokra is. Az akvakultúrák olyan mesterségesen létrehozott vízi környezetet jelentenek, ahol tengeri és édesvízi növényeket, állatokat (például halakat, rákokat, kagylókat és moszatokat) tenyésztenek valamilyen céllal, ami lehet ipari felhasználás, élelmiszertermelés vagy állománymegőrzés. A chilei vörös alga (Gracilaria chilensis C. J. Bird, McLachlan \& E. C. Oliveira, 1986) farmokon 1998-ban moszatinvázió kezdődött egy invazív zöld alga (Codium fragile Hariot, 1889) megjelenésével, ami rohamosan szétterjedt mind az északi, mind a déli farmokon. Agresszív, gyors szaporodása miatt nem tudott megbirkózni vele a helyi ökoszisztéma, ráadásul ahol megjelent, ott alkalmatlanná vált a terület a mủvelésre, vagy a mủvelés csak komoly költségek árán folytatódhatott (kémiai védekezés, kézi eltávolítás munkásokkal, elszállítás), ezért több farmot is be kellett zárni. A gazdák megélhetése veszélybe került. A Gracilaria fajok komoly gazdasági jelentőséggel bírnak: élelmiszeripari és kozmetikai alapanyagok. Vörös algából készül az agaragar is, mely világszerte elterjedt mikrobiológiai táptalaj. Az ezt kiszorító Codium alga igen veszélyes: 113 vizsgált európai algafaj közül a legkockázatosabbnak minősítették terjedési képessége és ökológiai hatása miatt. A kanadai akvakultúrákban is óriási, évi 1,2 millió dolláros károkat okoz a Codium invázió a hálók benövésével és a halak táplálékául szolgáló apró kis rákok mozgásának akadályozásával. A Chilét elárasztó Codium meglepő módon Japánból érkezett. De nemcsak Dél-Amerika csendes-óceáni partvonalát érte el, hanem eljutott Észak-Amerikába, Európába, Ausztráliába és Új-Zélandra is. Ahol megjelenik, ott mindent beborít: sziklákat, korallokat, rákokat, kagylókat, mesterséges tárgyakat, például köteleket vagy hullámtörő gátakat is. Sok helyen képes megélni, mivel széles türőképességű a hőmérséklet, sótartalom, fényviszonyok és tápanyag-elérhetőség tekintetében. Képes ivarosan és ivartalanul is szaporodni. Egy igazi inváziós faj. Azért tudott évek alatt ilyen gyorsan és ilyen távoli helyekre is eljutni, mert terjedését a tengeri mủanyagok segítették. Mủanyag bójákhoz tapadva 10 év alatt $1200 \mathrm{~km}$-t is képes volt megtenni, így szelte át az óceánokat. A természetes anyagok (például fadarabok, madártollak, termések) ilyen hosszú idő alatt lebomlottak volna. Tehát a mesterséges objektumok új folyosót nyitnak meg az egymástól távoli tengeri élőhelyek között, s közvetítik az olyan invazívvá váló fajok terjedését is, melyek hatalmas gazdasági károkat okoznak (Neill et al. 2006). 


\section{Konklúzió}

A cikk első részében részletes képet kaphattunk a müanyagok okozta szerteágazó környezeti problémáról. Egyértelmü, hogy a helyzetet nem lehet kezelni kizárólag természettudományos módszerekkel (pl. természetvédelmi biológia), de még müszaki tudományokkal (pl. óceántisztító berendezések) sem. Fel kell ismerni, hogy mélyreható társadalmi, gazdasági és politikai változások nélkül nem lehet eredményeket elérni. Nem szükíthetjük le a problémával való foglalkozást deskriptív megközelítésre, szükség van a normatív iránymutatásra is. A folytatásban erről fogok írni.

\section{Irodalomjegyzék}

Andrady, A. L. (2011): Microplastics in the marine environment. - Mar. Pollut. Bull. 62(8): 15961605. http://dx.doi.org/10.1016/j.marpolbul.2011.05.030

Arisawa, K., Takeda, H. \& Mikasa, H. (2005): Background exposure to PCDDs / PCDFs / PCBs and its potential health effects: a review of epidemiologic studies. $-J$. Med. Invest. 52(1-2): 10-21. http://dx.doi.org/10.2152/jmi.52.10

Barnes, D. K. (2002): Biodiversity: invasions by marine life on plastic debris. - Nature 416(6883): 808-809. http://dx.doi.org/10.1038/416808a

Barnes, D. K., Galgani, F., Thompson, R. C. \& Barlaz, M. (2009): Accumulation and fragmentation of plastic debris in global environments. - Philos. T. R. Soc. B: Biological Sciences. 364(1526): 1985-1998. http://dx.doi.org/10.1098/rstb.2008.0205

Browne, M. A., Crump, P., Niven, S. J., Teuten, E., Tonkin, A., Galloway, T. \& Thompson, R. (2011): Accumulation of microplastic on shorelines woldwide: sources and sinks. - Environ. Sci. Technol. 45(21): 9175-9179. http://dx.doi.org/10.1021/es201811s

Carson, H. S., Lamson, M. R., Nakashima, D., Toloumu, D., Hafner, J., Maximenko, N., \& McDermid, K. J. (2012): Tracking the sources and sinks of local marine debris in Hawai ,i. -Mar. Environ. Res. 84: 76-83. http://dx.doi.org/10.1016/j.marenvres.2012.12.002

Cole, M., Lindeque, P., Halsband, C. \& Galloway, T. S. (2011): Microplastics as contaminants in the marine environment: a review. - Mar. Pollut. Bull. 62(12): 2588-2597. http://dx.doi.org/10.1016/ marpolbul.2011.09.025

Cole, M., Lindeque, P., Fileman, E., Halsband, C. \& Goodhead, R. M., Moger, J., Galloway, T. (2013): Microplastic ingestion by zooplankton. - Environmenta science \& technology. 47(12): 6646-6655.

Derraik, J. G. (2002): The pollution of the marine environment by plastic debris: a review. - Mar. Pollut. Bull. 44(9): 842-852. http://dx.doi.org/10.1016/S0025-326X(02)00220-5

Do Sul, I. J. A. \& Costa, M. F. (2014): The present and future of microplastic pollution in the marine environment. - Environ. Pollut. 185: 352-364. http://dx.doi.org/10.1016/j.envpol.2013.10.036

Engler, R. E. (2012): The complex interaction between marine debris and toxic chemicals in the ocean. - Environ. Sci. Technol. 46(22): 12302-12315. http://dx.doi.org/10.1021/es3027105

Eriksen, M., Maximenko, N., Thiel, M., Cummins, A., Lattin, G., Wilson, S., Hafner, J., Zelleres, A. \& Rifman, S. (2013): Plastic pollution in the South Pacific subtropical gyre. - Mar. pollut. Bull. 68(1-2): 71-76. http://dx.doi.org/10.1016/j.marpolbul.2012.12.021 
Fendall, L. S. \& Sewell, M. A. (2009): Contributing to marine pollution by washing your face: Microplastics in facial cleansers. - Mar. Pollut. Bull. 58(8): 1225-1228. http://dx.doi.org/10.1016/j. marpolbul.2009.04.025

Gregory, M. R. (2009): Environmental implications of plastic debris in marine settings-entanglement, ingestion, smothering, hangers-on, hitch-hiking and alien invasions. -Philos. T. R. Soc. B: Biological Sciences. 364(1526): 2013-2025. http://dx.doi.org/10.1098/rstb.2008.0265

Faroon, O., Harris, M. O., Llados, F., Swarts, S., Sage, G., Citra, M., \& Gefell, D. (2002): Toxicological profile for DDT, DDE, and DDD. - US Department of Health and Human Services, Public Health Service, Agency for Toxic Substances and Disease Registry. (http://www.atsdr.cdc. gov/toxprofiles/tp35.pdf) Letöltés ideje: 2014.05.01.

Hirai, H., Takada, H., Ogata, Y., Yamashita, R., Mizukawa, K., Saha, M., Kwan, C., Moore, C., Gray, H., Laursen, D., Zettler, E. R., Farrington, J. W., Reddy, C. M., Peacock, E. E. \& Ward, M. W. (2011): Organic micropollutants in marine plastics debris from the open ocean and remote and urban beaches. - Mar. Pollut. Bull. 62(8): 1683-1692. http://dx.doi.org/10.1016/j.marpolbul.2011.06.004

Jambeck, J. R., Geyer, R., Wilcox, C., Siegler, T. R., Perryman, M., Andrady, A., Narayan, R. \& Law, K. L. (2015): Plastic waste inputs from land into the ocean. - Science. 347(6223): 768-771. http://dx.doi.org/10.1126/science.1260352

Kaposi, K. L., Mos, B., Kelaher, B. \& Dworjanyn, S. A. (2013): Ingestion of microplastic has limited impact on a marine larva. - Environ. Science Technol. 48(3): 1638-1645. http://dx.doi.org/ 10.1021/es404295e

Kershaw, P., Katsuhiko, S., Lee, S., Samseth, J., Woodring, D. \& Smith, J. (2011): Plastic debris in the ocean. - United Nations Environment Programme (UNEP) Year Book. pp. 20-33.

Krause, J. C., von Nordheimen, H. \& Brager, S. (2006): Marine Nature Conservation in Europe. (https://www.bfn.de/fileadmin/MDB/documents/themen/meeresundkuestenschutz/ downloads/Fachtagungen/Marine-Nature-Conservation-2006/Proceedings-Marine Nature Conservation_in_Europe 2006.pdf) Letöltés ideje: 2016.08.04.

Laist, D. W. (1987): Overview of the biological effects of lost and discarded plastic debris in the marine environment. - Mar. Pollut. Bull. 18(6): 319-326. http://dx.doi.org/10.1016/S0025326X(87)80019-X

Law, K. L., Morét-Ferguson, S., Maximenko, N. A., Proskurowski, G., Peacock, E. E., Hafner, J. \& Reddy, C. M. (2010): Plastic accumulation in the North Atlantic subtropical gyre. - Science. 329(5996): 1185-1188. http://dx.doi.org/10.1126/science.1192321

Lechner, A., Keckeis, H., Lumesberger-Loisl, F., Zens, B., Krusch, R., Tritthart, M., Glas, M. \& Schludermann, E. (2014): The Danube so colourful: A potpourri of plastic litter outnumbers fish larvae in Europe's second largest river. - Environ. Pollut. 188: 177-181. http://dx.doi. org/10.1016/j.envpol.2014.02.006

Martinez, E., Maamaatuaiahutapu, K., Taillandier, V. (2009): Floating marine debris surface drift: convergence and accumulation toward the South Pacific subtropical gyre. - Mar. Pollut. Bull. 58(9): 1347-1355. http://dx.doi.org/10.1016/j.marpolbul.2009.04.022

Mato, Y., Isobe, T., Takada, H., Kanehiro, H., Ohtake, C. \& Kaminuma, T. (2001): Plastic resin pellets as a transport medium for toxic chemicals in the marine environment. - Environ. Sci. Technol. 35(2): 318-324. http://dx.doi.org/10.1021/es0010498

McNeill, J. R. (2011): Valami új a nap alatt. - Ursus Libris, Budapest. 303 p., 349 p.

Moore, C. J. (2008): Synthetic polymers in the marine environment: a rapidly increasing, long-term threat. - Environ. Res. 108(2): 131-139. http://dx.doi.org/10.1016/j.envres.2008.07.025 
Moore, C. J., Moore, S. L., Leecaster, M. K. \& Weisberg, S. B. (2001): A comparison of plastic and plankton in the North Pacific central gyre. - Mar. Pollut. Bull. 42(12): 1297-1300. http://dx.doi. org/10.1016/S0025-326X(01)00114-X

Morét-Ferguson, S., Law, K. L., Proskurowski, G., Murphy, E. K., Peacock, E. E. \& Reddy, C. M. (2010): The size, mass, and composition of plastic debris in the western North Atlantic Ocean. Mar. Pollut. Bull. 60(10): 1873-1878. http://dx.doi.org/10.1016/j.marpolbul.2010.07.020

Neill, P. E., Alcalde, O., Faugeron, S., Navarrete, S. A. \& Correa, J. A. (2006): Invasion of Codium fragile ssp. Tomentosoides in northern Chile: A new threat for Gracilaria farming. - Aquaculture. 259(1-4): 202-210. http://dx.doi.org/10.1016/j.aquaculture.2006.05.009

Ogata, Y., Takada, H., Mizukawa, K., Hirai, H., Iwasa, S., Endo, S., Mato, Y., Saha, M., Okuda, K., Nakashima, A., Murakami, M., Zurcher, C., Booyatumanondo, R., Zakaria, M. P., Dung, L. Q., Gordon, M., Miguez, C., Suzuki, S., Moore, C., Karapanagioti, H. K., Weerts, S., McClurg, T., Burres, E., Smith, W., Van Velkenburg, M., Lang, J.S., Lang, R. C., Laursen, D., Danner, B., Stewardson, N. \& Thompson, R. C. (2009): International Pellet Watch: Global monitoring of persistent organic pollutants (POPs) in coastal waters. 1. Initial phase data on PCBs, DDTs, and HCHs. - Mar. Poll. Bull. 58(10): 1437-1446. http://dx.doi.org/10.1016/j.marpolbul.2009.06.014

PlasticsEurope (2013): Plastic - the Facts 2013. (http://www.plasticseurope.org/ Document/plastics-the-facts-2013.aspx?FolID=2) Letöltés ideje: 2014.05.01.

Rochman, C. M., Manzano, C., Hentschel, B. T., Simonich, S. L. M. \& Hoh, E. (2013): Polystyrene Plastic: A Source and Sink for Polycyclic Aromatic Hydrocarbons in the Marine Environment. Environ. Sci. Technol. 47(24): 13976-13984. http://dx.doi.org/10.1021/es403605f

Rockström, J., Steffen, W., Noone, K., Persson, Å., Chapin, F. S., Lambin, E. F., Lenton, T. M., Scheffer, M., Folke, C., Schellnhuber, H. J., Nykvist, B., de Wit, C. A., Hughes, T., van der Leeuw, S., Rodhe, H., Sörlin, S., Synder, P. K., Costanza, R., Svedin, U., Falkenmark, M., Karlberg, L., Corell, R. W., Fabry, V. J., Hansen, J., Walker, B., Liverman, D., Richardson, K., Crutzen, P. \& Foley, J. A. (2009): A safe operating space for humanity. - Nature 461(7263): 472-475. http:// dx.doi.org/10.1038/461472a

Ryan, P. G., Moore, C. J., van Franeker, J. A. \& Moloney, C. L. (2009): Monitoring the abundance of plastic debris in the marine environment. - Philos. T. R. Soc. B: Biological Sciences. 364(1526): 1999-2012. http://dx.doi.org/10.1098/rstb.2008.0207

Setälä, O., Fleming-Lehtinen, V. \& Lehtiniemi, M. (2014): Ingestion and transfer of microplastics in the planktonic food web. - Environ. Pollut. 185: 77-83. http://dx.doi.org/10.1016/j.envpol.2013.10.013

Shah, A. A., Hasan, F., Hameed, A. \& Ahmed, S. (2008): Biological degradation of plastics: a comprehensive review. - Biotechnol. Advances 26(3): 246-265. http://dx.doi.org/10.1016/j.biotechadv.2007.12.005

STAP (2011): Marine Debris as a Global Environmental Problem: Introducing a solutions based framework focused on plastic. - A STAP Information Document. Global Environment Facility, Washington, DC. (http://www.thegef.org/gef/sites/thegef.org/files/publication /STAP\%20MarineDebris\%20-\%20website.pdf) Letöltés ideje: 2014.01.14.

Thiel, M., Bravo, M., Hinojosa, I. A., Luna, G., Miranda, L., Núñez, P., Aldo S. P. \& Vásquez, N. (2011): Anthropogenic litter in the SE Pacific: an overview of the problem and possible solutions. - RGCI-Revista de Gestão Costeira Integrada 11(1): 115-134. http://dx.doi.org/10.5894/ rgci207

Van Franeker, J. A., Blaize, C., Danielsen, J., Fairclough, K., Gollan, J., Guse, N., Turner, D. M., Hansen, P-L., Heubeck, M., Jensen, J-K., Guilloum G. L., Olsen, B., Olsen, K-O., Pedersen, J., Stienen, E. W. M. \& Turner, D. M. (2011): Monitoring plastic ingestion by the northern 
fulmar Fulmarus glacialis in the North Sea. - Environ. Poll. 159(10): 2609-2615. http://dx.doi. org/10.1016/j.envpol.2011.06.008

von Moos, N., Burkhardt-Holm, P. \& Köhler, A. (2012): Uptake and effects of microplastics on cells and tissue of the blue mussel Mytilus edulis L. after an experimental exposure. - Environ. Sci. Technol. 46(20): 11327-11335.http://dx.doi.org/10.1021/es302332w

WEF, World Economic Forum (2016): The New Plastics Economy. Rethinking the future of plastics. (http://www3.weforum.org/docs/WEF The_New_Plastics_Economy.pdf) Letöltés ideje: 2016.06.01.

Wright, S. L., Thompson, R. C. \& Galloway, T. S. (2013): The physical impacts of microplastics on marine organisms: A review. - Environ. Poll. 178: 483-492. http://dx.doi.org/10.1016/j.envpol.2013.02.031

Wurpel, G., Van den Akker, J., Pors, J. \& Ten Wolde, A. (2011): Plastics do not belong in the ocean. Towards a roadmap for a clean North Sea. - IMSA Amsterdam. (http://www.plasticmarinelitter. eu/wp-content/uploads/2011/10/PML100 report-plastics-do-not-belong-in-the-ocean-DEF.pdf) Letöltés ideje: 2014.01.16.

Zettler, E. R., Mincer, T. J. \& Amaral-Zettler, L. A. (2013): Life in the ,Plastisphere': Microbial communities on plastic marine debris. - Environ. Sci. Technol. 47(13): 7137-7146. http://dx.doi. org/10.1021/es401288x

\title{
The complex impact of the plastic pollution in the seas and the oceans - part 1: Introduction
}

\author{
István Gubek \\ Eötvös Loránd University, Humanecology MA, \\ H-1117 Budapest, Pázmány Péter sétány 1/A, Hungary \\ e-mail:istvan.elte@gmail.com
}

The plastic pollution of seas and oceans is a more and more important search field in the recently years. It's a similar global environmental problem like climate change or the losses of biodiversity, nevertheless the publicity has much less information about it because this is a brand new area and it has not got a Hungarian literature yet. This is the first comprehensive article which was made by the detailed study of the international literature. In the first part I examine the complex impacts of plastics in the marine environment based on physical, chemical, biological, ecological, economical and social aspects. Later, in the second, ending part I will expound the already exist possible solutions.

Keywords: seas, oceans, plastics, environmental pollution, garbage patches, biodiversity, ecosystems, food chain 